\title{
QUEEN'S
UNIVERSITY
BELFAST
}

\section{Economic Citizenship and Workplace Conflict in Anglo-American Industrial Relations Systems}

Currie, D., \& Teague, P. (2016). Economic Citizenship and Workplace Conflict in Anglo-American Industrial Relations Systems. British Journal of Industrial Relations, 54(2), 358-384. https://doi.org/10.1111/bjir.12150

Published in:

British Journal of Industrial Relations

Document Version:

Peer reviewed version

Queen's University Belfast - Research Portal:

Link to publication record in Queen's University Belfast Research Portal

Publisher rights

(c) 2015 John Wiley \& Sons Ltd/London School of Economics.

This is the peer reviewed version of the following article: Currie, D. and Teague, P. (2015), Economic Citizenship and Workplace Conflict in Anglo-American Industrial Relations Systems. British Journal of Industrial Relations, which has been published in final form at http://onlinelibrary. wiley.com/doi/10.1111/bjir.12150/abstract. This article may be used for non-commercial purposes in accordance with Wiley Terms and Conditions for Self-Archiving.

\section{General rights}

Copyright for the publications made accessible via the Queen's University Belfast Research Portal is retained by the author(s) and / or other copyright owners and it is a condition of accessing these publications that users recognise and abide by the legal requirements associated with these rights.

Take down policy

The Research Portal is Queen's institutional repository that provides access to Queen's research output. Every effort has been made to ensure that content in the Research Portal does not infringe any person's rights, or applicable UK laws. If you discover content in the Research Portal that you believe breaches copyright or violates any law, please contact openaccess@qub.ac.uk. 


\title{
Economic Citizenship and Workplace Conflict in Anglo- American Industrial Relations Systems
}

\author{
Denise Currie \\ Queen's University Belfast \\ and \\ Paul Teague \\ Queen's University Belfast
}

* Corresponding author: Paul Teague, Queen’s Management School, Queen’s University Belfast, Riddel Hall, 185 Stramillis Rd, Belfast, BT9 5EE, N. Ireland 


\begin{abstract}
This paper argues that the expansion of individual employment rights is presenting a series of challenges to the collective model of economic citizenship that prevailed in most of the AngloAmerican world during the last century. We examine developments in the management of workplace conflict in Anglo-American countries to highlight the institutional manoeuvrings that have been taking place to mould the nature of national regimes of employment rights. We argue that Governments almost everywhere are actively seeking to create institutional regimes that weaken the impact of employment legislation and we find that statutory dispute resolution agencies are eagerly trying to develop organizational identities that are aligned with rightsbased employment disputes.
\end{abstract}




\section{Introduction}

Many lament the weakening of collective industrial relations processes, but few deny that it is occurring. When these processes were thriving, they gave rise to what might be called a collective model of economic citizenship: the economic status of those in employment was determined by collective bargaining reinforced to varying degrees by other collective institutional processes. However, this collective model of economic citizenship is now in retreat and has been for some time. A battery of initiatives and programmes has been pursued almost everywhere to revive this model, but it is fair to say without much success. In this context, it is important to ask the question: with the fraying of the collective model of economic citizenship what new institutions are emerging to invent the rights and obligations used to incorporate people into working life? In other words, is economic citizenship being institutionally reformed?

This paper suggests that the huge expansion in individual employment rights that has occurred almost simultaneously across Anglo-American countries is having a significant impact on the traditional collective model of economic citizenship. It seeks to tease out the nature and significance of the institutional changes taking place by examining the changing nature of workplace conflict and its resolution in the Anglo- American world. It suggests that a new 'rights-based' dimension is emerging to economic citizenship in these countries. Testimony to the significance of this development is the active attempts being made by Governments and employers across Anglo-American countries to institutionalise regimes of individual employment rights that are business friendly. Moreover, statutory dispute resolution agencies, once an institutional buttress of collective industrial relations, are seeking to reinvent themselves so that their services are more aligned with new emerging 'rights-based' patterns 
of workplace conflict. All in all, the paper suggests that economic citizenship may be institutionally mutating in the Anglo-American world.

The paper is organized as follows. The first section explains the concept of economic citizenship and shows how for a good part of the $20^{\text {th }}$ century it was embedded in a battery of collective industrial relations institutions in Anglo-American countries. The following section suggests that the collective model of economic citizenship has been under pressure for some time and identifies the big expansion of employment legislation on individual rights across the Anglo-American world as a significant cross-country institutional development. The third section examines the extent to which the growth of individual employment rights should be seen as one example of the wider juridification of economic and social life. Next we assess attempts at creating a private ordering of the employment relationship in response to these juridification developments. The penultimate section assesses how the rise of individual employment rights has encouraged public dispute resolution bodies to reconstitute themselves internally in an effort to be aligned with rights-based employment relations activity. The conclusions bring together the arguments of the paper.

\section{Industrial Relations and Economic Citizenship}

Normally, a range of institutional rules and procedures are used to not only incorporate people into the labour market, but also to shape expectations and obligations that employees, employers and societies have for work and employment relationships (Grahl and Teague 1994). We call this economic citizenship, but others use different terms: for example, Kochan (1999) uses the notion of a social contract. For most of the $20^{\text {th }}$ century, Anglo-American countries had national regimes of economic citizenship, which shared both similar and distinctive features. Like Jackson and Kirsch (2014), we consider it important not to follow the varieties 
of capitalism approach and characterize these countries as possessing a set of tightly prescribed common institutional traits that warrants the label of liberal market economies. The term Anglo-American world is preferred. On the one hand, it captures the reality of the countries making up this world having sufficiently common institutional features that allows them collectively to stand apart from other industrial relations systems. On the other hand, it is sufficiently open to recognize that important national institutional differences exist within the Anglo-American world. Industrial relations in the Anglo-American world consist of a distinctive bundle of converging and diverging institutional features.

In terms of economic citizenship these countries possessed regimes that were strongly collectivist in character and tended to exhibit a number of institutional features. Almost everywhere trade unions were assigned a special public status and played an important role in securing and upholding economic citizenship. Typically, trade unions entered into a collective agreement with employers which involved balancing conflicting interests to ascribe rights and obligations to individual workers and enterprises in a way that tended to exclude serious conflict between them (Streeck 2005). With the possible exception of the USA, this collective model of economic citizenship drove the forward march of labour during the 1950s and 1960s.

This collective model of economic citizenship was influential in setting pay and working conditions for employees in different organizations. It also underpinned the functioning of occupational labour markets. By validating economy-wide training and skills qualifications systems, collective industrial relations institutions conferred on workers pre-contractual rights as a series of expectations and obligations were created for employees and employers about how work should be organized and the employment relationship managed (Streeck 2012). Thus, membership of an occupation or craft became a status relationship which ran in parallel 
with the contracts entered into by individuals. The specific nature of services and of remuneration is governed by free contract, but is embedded in an invariant structure of obligations which ensures the competence, responsibility and probity of the practitioner. The client or firm thus had a guarantee which made it possible to employ or transact with any recognized member of an occupation: the counterpart of this for craft workers was precisely their mobility from one client or firm to another (Ryan 2010).

Solving workplace conflict was also influenced by the collective model of economic citizenship. Typically, formalised procedures, usually embedded in collective agreements, operated to address workplace disciplinary and grievance matters, as well as disputes that arose between unions and employers (Lewin 2008). In relation to grievances affecting individuals or disputes affecting groups of employees, the procedures normally involved several formal steps, the first of which required employees to put in writing a grievance or to register a dispute in an equally formal manner. After submitting a formal grievance, the individual employee was normally represented by a trade union shop steward and then possibility by a trade union official if the grievance travelled up the organizational hierarchy. In the same way, a dispute affecting a group of employees was commonly addressed initially at a first stage of procedure by an engagement between the parties immediately affected and management. On the management side, progressively higher levels of managers become involved if the grievance or dispute was not resolved at the first or intermediary stage of the procedure. The last stage of the procedure invariably involves a formal adjudication of the grievance or dispute. Thus, in the post-war period economic citizenship involved using collective institutions to establish the terms through which people were incorporated into working life (Edwards 1986). 
It is not excessive to argue that this collective model of economic citizenship created public goods in the labour market. Economic theory tends to see public goods as given; as determined by objective characteristics of the good in question that prevent it from being privately appropriated. It is more realistic, however, to see public goods as socially constructed; as being based on a gradually widening recognition of the common benefits arising from a particular type of public provision and of how that provision might be arranged (Touffut 2003). Although voluntarist in character and not formally part of the State, collective employment relations in Anglo-American countries operated in a way that produced, almost by surrogate, public good effects. An important outcome of the institutions of collective economic citizenship was to connect together in a complementary way equity and efficiency.

Establishing economic citizenship through collective industrial relations institutions was more or less common to all Anglo-American countries - it was a key convergence dynamic. At the same time, the institutional architecture of this collective model of economic citizenship differed across these countries. In the UK and Ireland, the organizing principle of collective economic citizenship was created and sustained by a system of voluntarist industrial relations. A voluntarist system of industrial relations is premised on freedom of contract and freedom of association, and in terms of the British/Irish tradition, is based on free collective bargaining on the one hand and relative legal abstention in industrial relations on the other. At the same time, the voluntary tradition never meant a total rejection of public intervention or labour law, but merely a preference for joint trade union and employer regulation of employment relations.

Sometimes, it is suggested that voluntarist industrial relations was an institutional feature of all Anglo-American countries in the era of collective economic citizenship. However, this is a mistaken view. In Australia and New Zealand, for most of the $20^{\text {th }}$ century, there was a fair amount of regulation of wage determination through a national system of conciliation and compulsory arbitration (see Lansbury and Wailes 2011 and Walsh 1993). New Zealand 
possessed a series of Conciliation Boards alongside a Court of Arbitration, which regularly intervened in wage bargaining either to resolve disputes or to impose a settlement. A similar process took place in Australia through a series federal and state tribunals bodies, including for most of the early/middle part of the $20^{\text {th }}$ century the Commonwealth Conciliation and Arbitration Commission and the Commonwealth Industrial Court, which functioned to conciliate and arbitrate industrial disputes. As a result, there was much greater state intervention in the collective bargaining process, which had the effect of establishing a floor of wage rates in many economic sectors.

The collective bargaining systems in the USA and Canada, although not fully similar, have more in common with each other than with other countries in the Anglo-American world (Troy 2000). In both countries, a system of federal and state (provincial) bodies was created to certify trade unions as the bargaining agents for particular groups of workers. This certification process imposes an obligation on the employer to engage in collective bargaining. Within this system, both employers and trade unions have a duty to bargain in good faith, with an expectation that strikes or lock-outs would not occur during the period of a collective agreement. In both countries, a battery of dispute resolution processes were established, including facilities for conciliation, mediation and arbitration, to assist the negotiation of collective agreements as well as to address any conflict concerning the interpretation and applicability of any collective agreement. Yet important differences exist between the USA and Canada. First of all, the nuts and bolts of the certification procedures differed in important ways between the two countries. Secondly, while compulsory arbitration is built into most collective bargaining agreements, Canada possesses more active public dispute resolution bodies, mostly at provincial level, to assist parties seeking to settle workplace disputes. In the USA, apart from the Federal Mediation and Conciliation Service (FCMS), no statutory body 
exists to address employment-related disputes, particularly of an individual kind - these have to be channelled into the formal judicial process.

Thus, there was a fair degree of divergence in the national institutional structures that housed the collective model of economic citizenship across Anglo-American countries. Despite this diversity, this collective model of economic citizenship has been under severe pressure for some time, fragmenting almost everywhere, and although it has not disappeared, it has been seriously weakened. Fewer and fewer employees are being incorporated into work and employment through collectively determined terms and conditions. Apart from a few enclaves in the private sector, collective models of economic citizenship are mostly the preserve of public sector employment in Anglo-American countries, even though these sectors are encountering the turbulent gales of restructuring and retrenchment.

$<$ Figure 1 here $>$

The two big indicators of the fragmentation of collective economic citizenship are the decline of trade union density and the sharp fall in collective-based employment disputes across AngloAmerican countries. In line with a universal trend, trade union density levels, as shown in Figure 1, have declined in all these countries over the past three decades, in some cases sharply, to the extent that everywhere only a minority of private sector employees are unionized: in all countries, aggregate density rates are buoyed by higher membership levels amongst public sector employees. In most countries, the incidence of collective employment disputes has reached record low levels - the trend is set out in Figure 2. Most of the disputes that do occur are related to public sector issues. It is not an exaggeration to suggest that strike action as a strategic option for private sector trade unions is virtually extinct. Only the most optimistic would deny that the old collective model of economic citizenship is not under serious institutional stress. 


\section{$<$ Figure $2>$}

Thus, the fragmentation of collective economic citizenship is pervasive and on-going. All sorts of initiatives have been launched to revitalise the model, including the promotion of workplace partnerships, the development of community-based unionism, and new organising/mobilization campaigns. Although it would be harsh to say these initiatives have failed, they have not been fully successful either - collective economic citizenship remains languishing in the Anglo-American world. With this being the case, it seems important to pose the Polanyian question: are new alternative institutional mechanisms emerging that are laying the ground rules through which people are being incorporated into the world of work? Is collective economic citizenship being institutionally reshaped? In our view, this matter has not been addressed sufficiently in the literature of economic life. As a result, we consider it important to consider the implications from the rise of individual employment rights, one of the few notable trends to emerge simultaneously across Anglo-American countries, for economic citizenship.

\section{The Emergence of Employment Rights}

Across all Anglo-American industrial relations systems there has been a big expansion of individual employment rights legislation. Table 1 below tries to capture this development. It shows that nearly all aspects of the employment relationship are governed by some form of legally-based employment right or standard. Employment legislation relating to pay, terms and conditions of employment, working hours, health and safety as well as equality at work, dismissal and redundancy situations and so on exists in one form or another in all AngloAmerican countries. The growth of individual employment rights can be traced back to the 1970s when equal pay legislation was introduced universally across advanced countries. Since then the scale and complexity of individual employment rights legislation has steadily 
accumulated across countries. This is a genuinely common dynamic across Anglo-American employment relations systems.

\section{$<$ Table 1 here $>$}

The emergence of a sizable body of individual employment rights has led to the significant, sometimes massive, growth in the number of legally-based individual employment disputes. It is hard to graph this trend in the Anglo-American world given the country disparities in the way these cases are classified and the various institutional avenues open to employees to pursue claims, but it is common across countries. For the most part, the emergence of individual employment rights and standards is not cast in a positive light in much of the industrial relations literature. Colvin and Darbishire (2013) discuss the growth in this type of legislation, but bestow little significance on it. They suggest that the growing body of legislation on individual employment rights across the Anglo-American world has only created a minimalist legal exoskeleton for labour markets, unable to influence in any appreciable way the private ordering of the employment relationship. A similar argument is presented by Pollert (2007) who suggests that the growth of individual employment rights during the past two decades are paper tigers as they have not provided meaningful protection for those in low paid, precarious jobs. This derisory assessment of the emergence of a quite significant body of individual employment rights, which has occurred in all Anglo-American countries, reflects a common view in the industrial relations literature (see Dickens 2012 and Smith and Morton 2006).

For sure, hefty criticisms can be made of employment rights regimes that have emerged in Anglo-American countries. Yet it may be misguided to downplay this development too much as there are grounds for believing that the growth of individual employment rights legislation might be more than 'a residual set of protections on a few specific issues' (Colvin and Darbishire 2013 p1050). In his seminal work, the Theory of Communicative Action, Habermas (1987) argues that modern societies are becoming more juridified. He considered this 
juridification process as consisting of a number of interdependent elements. One is that law comes to regulate an ever increasing range of social and economic life. Another is that the resolution of all sorts of social and economic conflicts is secured through the use or with reference to the law. A further element is the growing power of the legal profession and the legal system more generally. A final element is the creation of a legal framing process, which encourages people to increasingly think of themselves and others as legal subjects. This framework can be employed to suggest that the expansion of individual employment rights may be more important than is often suggested in the industrial relations literature: a juridification process may be taking hold with regard the governance of the employment relationship in Anglo-American countries.

Using the law as a basic frame of reference to protect and advance employment protection has not emerged as a coherent industrial relations model anywhere even though some employer groups across Anglo-American countries repeatedly complain that employment legislation has produced a litigious culture at the workplace. Yet, the huge increase in the number of rightsbased workplace disputes in the wake of the adoption of employment rights legislation across the Anglo-American world strongly suggests that employees are more readily prepared to use the law to address work related matters. A stark example of this behaviour is in the UK where low paid women workers have successfully used 'no win no fee' solicitors to lodge equal pay cases at the Employment Tribunal. It is estimated that over 50,000 of such claims have been lodged so far by local government workers and 10,000 by health care workers. Some estimates suggest that compensation payments in these cases could cost up to $£ 10$ billion. Other big companies such as Asda and Sports Direct have also been on the losing end of cases brought to employment tribunals by employees with the use of 'no-win no fee' solicitors.

Thus, the juridification of labour markets centred largely on the growth of individual employment rights may not automatically fit with the collective model of economic citizenship. 
A key element of this model was the buttom-up delegation of authority from employees to trade unions. Trade unions were authorized to make collectively binding decisions in a top-down manner and had the ability to police these collective agreements. Rights-based employment legislation may compromise this monopoly power of trade union representation since it creates a process whereby people interact with matters relating to work and employment as legal subjects and not as members of a trade union: employees may view it as legitimate to use employment legislation to defend or advance rights at work without the involvement of trade unions. On this view, rights-based employment legislation may weaken the collective model of economic citizenship as employees come to view the law and not trade unions as the guarantor of their rights at work (Heery 2010).

It is for this reason that industrial relations scholars have been uneasy about governing the employment relationship through the use of employment rights. It is seen as resting too much on decentralized, uncoordinated action by individual employers, which may have the unintended consequence of marginalizing collective action. However, rights-based employment legislation should not be seen as antithetical to trade unionism or collective industrial relations. Across the Anglo-American world, trade unions have proven themselves adept at using these laws periodically to protect or advance the interest of their members. A survey of trade union officials in Ireland found that while they believed in the superiority of collective bargaining, they were also prepared to use the law to advance the interests of their members (O’Sullivan et al 2015). A common enough practice is for trade unions to embark upon 'strategic litigation' to try and advance legally-based employment protection, not least for vulnerable workers. Thus, trade unions can use employment legislation to augment traditional forms of collective action. As a result, the expansion of individual employment rights, in theory at least, may not be fully corrosive of the collective model of economic citizenship. At the same time, employment rights regimes and the traditional collective model 
of economic citizenship are unlikely to sit side-by-side with each other in a neat and tidy manner. More plausibility, employees (and trade unions) will sometimes use collective processes and at other times legal processes to protect their interests at work. In other words, economic citizenship is likely to be more disorganized. The extent of the disorganization or the extent to which legal processes dominate over collective processes (and visa-versa) within any Anglo-American country is likely to be contingent on prevailing economic and political circumstances. This view of rights-based and collective employment relations activity sitting haphazardly together is consistent with the fragmentation of national systems of industrial relations thesis.

A more positive view of individual employment rights regimes, particularly if these provided employees easy access to a range of mechanisms for the claiming, monitoring and enforcing of rights, is that public spaces could be created not only for the upholding of employment rights by a multiplicity of diverse groups, but also for encouraging discussions and campaigns for new ways of organizing employment relations and new rules for securing greater cohesion in the labour market. In other words, it may be too narrow to view rights-based employment legislation as giving rise to purely individualized forms of labour market action. It may also create opportunities for the mobilisation of what Heckscher and McCarthy (2014) call 'new solidarities' where people come together collectively to launch purposeful yet transient campaigns. On this view, a rights-based model of economic citizenship may be emerging that is as much about developing capabilities, deepening participation and promoting accountability as it is about the formal acquisition of legal rights.

Thus, as Piore and Safford (2006) argue, employment rights may give rise to new, albeit more fragmented, forms of social mobilization on work-related matters. They suggest that the expansion of employment rights legislation may be facilitating the emergence of a new identity politics at the workplace: people increasingly think of themselves in terms of religion, gender, 
sexual preference and ethnicity rather than class. At the workplace many of these different groups have come to see their problems related to their social identities and not to their position as employees. In this situation, identity groups use the legislative and judicial options open to them to address employment-related issues that are seen as blocking their interests at work. For example, across Europe equality groups have used EU Directives to challenge the perceived limitations of domestic employment legislation. In the USA, gay and lesbian groups are using legal strategies to realise same-sex pensions. Thus, the emergence of rights-based employment legislation behaviour may be allowing employees realize their social identities at work by mobilizing in a manner that does not necessarily involve organized labour.

This alternative view hints at the emergence of a new rights-based model of citizenship that mutates the old collective model. Under this model, economic citizenship is not institutionally embedded in well-ordered industrial relations systems. Labour markets are not likely to be tightly organised due to the presence of a range of encompassing institutional arrangements. Collective bargaining will continue to play an important role in setting the terms and conditions through which employees are incorporated into workplaces. At the same tie, a rights-based model of economic citizenship envisages more decentred and multifarious forms of collective action in labour markets: the protection and advancement of employee interests at work are likely to be seen as being secured by a multiplicity of social groups using a variety of mobilization strategies. Accordingly, the representative monopoly enjoyed by trade unions will be weakened, but not marginalized. At the same time, it is a model that emphasizes that individuals will only fully realize themselves and their interests by actively engaging in wider labour market-related and civic associations (Rosanvallon 2006). Few serious discussions are occurring in the industrial relations literature about a rights based model of economic citizenship. There is even little discussion about the extent to which the juridification of modern life may be fragmenting economic citizenship into individual and collective components. 
In the absence of these discussions, the general trend is to treat the expansion of employment rights as having next to no far reaching impact. Yet, if we look across the Anglo-American world active efforts are occurring to design institutional arrangements to dull the impact of the expansion of employment rights, a process that is particularly manifest in relation to workplace conflict and its resolution. In most Anglo-American countries, Governments backed by employers have been actively pursuing strategies aimed at weakening the impact of individual employment rights legislation: hoping to design employment rights regimes that are businessfriendly. In the same vein, public dispute resolution bodies in Anglo-American countries have responded to the growth of rights-based workplace conflict by seeking to shred the organizational identity that ties them to collective industrial relations processes. Instead they are seeking to develop a new identity that is more aligned with rights-based, individualized forms of employment conflict. In other words, the emergence of rights-based employment legislation has led to a flurry of institutional activity and organizational innovation that mostly seeks to weaken the impact of employment legislation, to reducing the possibilities of any significant moves towards a rights-based model of economic citizenship. These developments suggest that the steady expansion of individual employment rights legislation is anything but a side-show: if the rise of individual employment rights is so innocuous why is so much effort being made to ensure these are implemented in a business-friendly manner? The nature and extent of these efforts are discussed below.

\section{Individual Employment Rights and the Institutional Ordering of the Employment Relationship}

The proliferation of individual employment rights has had important, although diverse, effects on public policy frameworks used to manage workplace conflict. In the United States, probably the country with the weakest institutional support arrangements to assist workplace conflict resolution, the emergence of employment rights has triggered a decisive move towards the 
private ordering of the employment relationship (Estlund 2010). Unlike most other AngloAmerican countries, the USA never created a body like an employment tribunal or industrial relations court to address specifically legally-based employment disputes. As a result, cases of this kind had to be addressed by the normal civil court system. Of course, this made the vindication of legally-based employment disputes a very legalistic, costly and protracted affair - on average it takes a minimum of 2 years before a case gets to trial (Colvin 2012). Despite these undoubted hurdles, a massive jump occurred in the number of employment-related legal cases going before the courts during the 1990s. A factor fuelling this increase was the big financial awards secured by successful claimants: the median award in successful cases in statelevel courts was $\$ 176,000$ while the median figure for successful cases in Federal Courts was $\$ 394,000$. Thus, potentially handsome rewards awaited those prepared to endure the arduous legal journey to vindicate employment rights.

Employers were obviously nervous that the enlarged body of statutory employment rights was triggering a major increase in litigation cases against organizations with potentially large costly implications. In response, some organizations began writing employment contracts which required prospective employees to sign, as a condition of recruitment, a commitment to arbitrate alleged breaches of statutory rights and forgo their right to pursue their case in the courts (Stone 2000). Considerable uncertainty existed about the legality of obliging potential employees to waive their right to use the courts to vindicate alleged breaches of employment law. However, this uncertainty was cleared up when in 1991 the USA Supreme Court ruled in the Gilmer case that it was legally permissible for organizations to ask employees to use arbitration to resolve legally-based employment disputes. This decision gave employers the green light to develop employment contracts that contained binding arbitration clauses as an alternative to litigation. Contracts of this kind make it legally difficult for workers to use the 
courts to enforce statutory employment rights (Lipsky et al. 2003). As a result, the number of employment contracts stipulating that employment disputes will be settled by arbitration has increased significantly, with the effect of blocking off many employees from a battery of employment rights. Legally-based employment grievances are increasingly being addressed through private systems of justice operating inside organizations (Lipsky and Avgar 2008).

Australia and New Zealand have been travelling a turbulent institutional path triggered largely by political efforts to weaken the public dimension to workplace dispute resolution. In New Zealand, a root and branch transformation of existing institutional support systems for collective industrial relations was attempted through the Employment Contracts Act 1991 (Grills 1994). This piece of legislation ended state registration and regulation of trade unions and abolished the rewards systems that allowed public institutions to intervene in collective bargaining processes and effectively establish going-rates-of-pay in particular business sectors. Two new institutions were created - the Employment Tribunal and the Employment Court with the purpose of breaking up the monopoly role of trade unions as gatekeepers of employment disputes. Individual employees found it easier to pursue employment disputes on their own which resulted in the number of personal grievance cases soaring. Although the new established Employment Court could use semi-judicial processes to resolve individual employment disputes, the strong preference was for the Employment Tribunal first to use mediation and then arbitration to reach settlements.

The Act also strongly advocated the resolution of employment disputes within organizations. Thus, the Act was a radical plan to weaken collective industrial relations and create an overarching institutional structure for individual employment disputes, with a strong emphasis on non-judicial resolution methods (Walker and Hamilton 2009). Unsurprisingly, trade unions 
strongly opposed this development, claiming it represented a 'privatization' of the dispute resolution system. As a result, when a Labour Government regained power it passed the Employment Relations Act 2000, which sought to shift the balance towards collective bargaining and away from individual employment rights (Waldegrave et al. 2003). However, these efforts to give collective bargaining and trade unionism a shot in the arm have had limited success and the New Zealand institutional system to support the resolution of workplace conflict remains firmly focused on individual disputes.

Like New Zealand, the hallmarks of the Australian collective industrial relations systems was a centralized conciliation and arbitration system and an awards system that ensured public regulation of aspects of wage setting by organizations. These twin pillars of collective industrial relations system were weakened somewhat by the Industrial Relations Reform Act 1993, but more far reaching change was wrought by two subsequent pieces of legislation, the Workplace Relations Act 1996 and the Workplace Relations Amendment Act 2005 (Work Choices) (Teicher et al. 2006). The effect of these two pieces of legislation was to place restrictions on which employees could pursue unfair dismissal employment disputes, restrict the cases where the Australian Industrial Relations Commission could engage in compulsory arbitration and (strongly) promote the role of private mediators and consultants in solving workplace conflict within organizations. In a further effort to strengthen the role of private mediation, an Alternative Dispute Resolution Assistance Scheme (ADRAS) was introduced in 2006, which provided employees with financial subsidies to use private mediators to address their employment grievance/dispute.

These initiatives have been interpreted as not only an attempt to marginalize collective industrial relations processes in the country, but also to weaken the ability of employees to use 
legal processes to vindicate employment rights: public policy was promoting a private justice regime to resolve legally-based workplace conflict (Van Gramberg 2006). This new regime was stoutly opposed by trade unions and some politicians, which explains why one of the first moves of a new Labour Government elected in 2008 was to introduce the Fair Work Act 2009 that sought to re-establish public support mechanisms for collective bargaining. A new Fair Work Commission was created to encourage ‘good faith' collective bargaining. The legislation also created the Fair Work Ombudsman (FWO) with the authority to investigate complaints or suspected contraventions of workplace laws, awards, and agreements and to initiate legal proceedings to enforce workplace laws. It also has the role of providing employers with accurate and timely information about fair work practices, rights and obligations. The establishment of the FWO is interesting as it can be viewed as an attempt to stop the creep of a privatised justice regime for individual employment rights by creating, on paper at least, a relatively easily accessible public body to assist employees seeking vindication of employment rights (Forsyth 2012). However, it is too early to say whether it is being successful in performing this role, although initial indications are positive.

In the UK, the institutional structure established to assist the resolution of collective industrial disputes has more or less stopped functioning. Saundry and Gill (2014) estimate that ACAS the main statutory agency charged with assisting the successful resolution of employment disputes - dealt with about 3,000 annual requests for collective conciliation during the midseventies compared to 9 per year during 2010-2013. Unsurprisingly, the public policy debate in the country has very much focused on the efficacy of Employment Tribunals in dealing (mostly) with individual employment disputes. Although this debate has straddled both Labour and Conservative Governments, its complexion has stayed the same. In particular, a consensus has emerged in Government circles that Employment Tribunals established to operate as 
relatively informal, easily accessible bodies for the speedy resolution of employment disputes have lost their way (Colling 2010). Various government-sponsored reports have portrayed employment tribunals as being overly formalistic, legalistic and cumbersome and as a result almost not fit-for-purpose to cope with the growth of cases being lodged with them (see for example Gibbons 2007).

Thus, the debate about the rise of individual employment legislation in the UK has not been framed in terms of making it easier for employees to vindicate rights or designing more effective enforcement strategies, but about addressing legally-based employment grievances as informally as possible. The expressed aim of public policy is to reduce the amount of cases heard by employment tribunals by developing more non-legalistic procedures through which claims have to pass through before they reach a full hearing (BIS 2011). Side-by-side with these efforts to address legally-based disputes informally, there has been several policy proposals made by Government advisors, backed up by a concerted business lobby, to weaken the scope and depth of existing employment rights. Overall, the narrative of employment rights placing an unnecessary burden on business is more pervasive than the counter story that employees, particularly those in precarious jobs, should be able to vindicate their employment rights easily.

In contrast to other Anglo-American countries, Ireland is an interesting case. Even though Ireland also experienced the big expansion in individual employment rights legislation that was occurring elsewhere, there has been no neo-liberal assault on the country's statutory dispute resolution agencies (see Teague 2013). To a large extent, this is due to the country having until recently a national system of social partnership, which functioned mostly to veto change rather than to advance employment relations innovations. Instead, the effect of the new regime of 
individual employment rights was to elevate the importance of one service - the Rights Commissioners - relative to other public dispute resolution agencies. Established in 1969, the original remit of the Rights Commissioners service was to help settle deadlocked small-scale collective industrial relations disputes in a non-legalistic manner. However, over the years the role of the Rights Commissioners within the Irish public dispute resolution system has changed significantly. In particular, the service gradually acquired a quasi-judicial role with respect of employment rights. No fewer than 19 pieces of legislation give Rights Commissioners an active role in the settlement of disputes (in 1995 the figure was 3). Thus, Rights Commissioners now have the double-barrelled role of problem solving disputes and vindicating employment rights: they can be legalistic and putative in their approach by seeking to reinforce legislation, but also accommodative and supportive when necessary by encouraging informal solutions to workplace problems (Hahn and Teague 2013). The changing role of the service has resulted in the total number of cases addressed by the Rights Commissioners service multiplying by more than nine times in the past 10 years.

The Rights Commissioners is now by far the busiest part of the Irish dispute resolution system. More importantly, its institutional design, which does not have a counterpart in other AngloAmerican countries with the possible exception of the newly created Fair Work Ombudsman in Australia, appears to be well-suited to the new emerging model of rights-based economic citizenship. The evidence suggests that people in precarious employment find it a relatively accessible service (Hahn and Teague 2013). Moreover, its reluctance to enforce prescriptive rules mechanistically, preferring instead to use its discretionary authority to work out customized solutions to specific disputes allows it to secure compliance with employment standards without being overly legalistic. Other Anglo-American countries could certainly learn from this service. Currently, the Irish dispute resolution system is being reformed to make 
it a more streamlined service. For the most part, this is an administrative exercise and will not lead to radical change in how disputes are addressed in the country. The Rights Commissioners are likely to remain the most important conflict management service.

Because the Canadian statutory dispute resolution system is so dispersed across a number of different institutions at both federal and provincial levels of government, identifying a pattern or single response to the emergence of a rights-based employment relations regime is not easy. But it is fair to say that there has been no concerted effort to uproot established public/statutory agencies concerned with resolving employment disputes. Bodies like the Labor Program Inspectors have seen their work increase significantly as a result of the rise in legally based disputes. The Human Rights Commission of Canada too has seen a big increase in the number of workplace discrimination cases it is handling. For the most part, it has largely been a case of institutional continuity. One interesting development has been to get different Federal agencies to work more closely with each other to address workplace disputes related to alleged breaches of employment rights. Thus, for example, after the comprehensive and insightful Government sponsored report Fairness at Work: Federal Labour Standards for the 21st Century was published in 2006, Labor Program Inspectors and the Human Rights Commission started collaborating closely with each other.

Overall, the political response to the rise of individual employment rights has varied across Anglo-American countries. In the USA, the move towards the private ordering of the employment relationship has been decisive, probably less so in other countries. In the UK, successive Governments have successfully framed the policy debate about the rise in employment rights around the need to increase the informal resolution of workplace conflict rather than on the importance of creating new institutional support mechanisms to allow 
employees to vindicate employment rights. But efforts at creating the private ordering of the employment relationship have been resisted, although perhaps not completely, in Australia and New Zealand where the matter of a public dimension to workplace conflict management has been a highly politically contentious matter. Attempts at private ordering of the employment relationship have not been successful in either Canada or Ireland. In fact the Irish case is interesting for the country’s Rights Commissioners service appears to combine successfully informal problem-solving and formal legal enforcement roles. Other countries could learn from this service, but overall there is a lack of clear, developed discussion about the most appropriate institutional architecture for the effective enforcement of individual employment rights.

\section{Individual Employment Rights and Institutional Adaptation}

Across the Anglo-American world during the collective economic citizenship era there was recognition that occasionally disputes would get so intractable that the parties involved would require external assistance to resolve the conflict. As a result, it was widely accepted that statutory rules of the game or procedures were needed to assist the resolution of workplace disputes that had reached an impasse (Dunlop and Zach 1997). Although, the actual design of statutory dispute resolution procedures varied considerably across Anglo-American countries, most countries created some form of quasi-governmental agency or service to provide a range of conflict management procedures - usually some combination of arbitration, conciliation and mediation, if not all three - to help solve mostly collective workplace problems. Invariably, information, advice and training were also provided to encourage high quality dispute resolution processes in organizations. Overall, the lion's share of the work of the public dispute resolution agencies addressed workplace conflict that was collective in nature. With the continuous fall-off in strikes and related forms of collective industrial relations disputes, almost 
everywhere these agencies have found that they no longer need to commit the level of resources previously necessary to address this form of workplace conflict. Perhaps more importantly, some of these organizations have become concerned that their very raison d'etre is in jeopardy such has been the scale of decline in collective industrial disputes. Thus, over the past decade a trend common to all Anglo-American countries has been efforts by public employment dispute resolution agencies to introduce a series of internal reforms aimed at aligning their organizations more fully with the individualized character of much contemporary workplace conflict.

In the USA, the Federal Conciliation and Mediation Service (FCMS), established in the first instance to assist trade unions and employers settle collective bargaining disputes, has been busy on a number of fronts in its endeavours to reshape its organizational identity. First of all, it has sought to broaden its customer base by offering conflict management services to help settle environmental, community and commercial problems. In other words, it no longer wishes to deal exclusively with conflict associated with management of the employment relationship. In addition, the organization has been eagerly trying to commercialize its activities by offering a wide range of fee paying conflict management training programmes both inside the USA and internationally (Strimling 2002). In relation to workplace conflict management, the FCMS has sought to get in tune with emerging trends in relation to organizational conflict management systems by actively promoting the diffusion of a range of ADR practices. Its active support for the development of a workplace ADR system at the United States Postal Service (UPSS) is one renowned example of this type of activity (Bingham 2003).

In Canada, various public employment dispute resolution agencies at federal and provincial level have sought to reorient what they do by increasing the number of informal, non-judicial 
dispute resolution services they deliver. Most of these concern the development of some type of ADR initiative to encourage the settlement of (mostly) individual-based workplace disputes informally. The Public Service Relations Board in the early 2000s launched an innovative Informal Conflict Management initiative with the aim of diffusing in different parts of the public sector a set of interrelated ADR procedures that could be used separately or together to settle workplace problems quickly and fairly (Thompson and Slinn 2013). Also in the early 2000s, the Canadian Human Rights Commission, which is responsible for addressing employment discrimination and equality cases that arise under Federal law, radically changed the manner in which it addressed complaints. In particular, it introduced a battery of what it termed ADR procedures to address discrimination and equality cases, including the establishment of a new pre-complaint service, the introduction of a professional and integrated new mediation and conciliation services to try and solve complaints informally (Slinn and Hurd 2011).

The Canadian Federal Mediation and Conciliation Service introduced a new suite of preventive and grievance mediation and conciliation initiatives to help resolve collective industrial disputes. Labour Program Inspectors, responsible for implementing various parts of the Canadian Labor Code, also experienced a change of working methods. Instead of doing investigations to prepare the groundwork for formal adjudication hearings, inspectors were encouraged to make greater use of mediation and conciliation methods to settle disputes. Thus, the Canadian statutory dispute resolution agencies have sought to reform from within to avoid having to rely solely on formal semi-judicial methods to address legally-based employment complainants. Promoting informal conflict management procedures in the face of the emergence of formal employment rights appears to be the dominant strategy. 
In the UK, ACAS has responded to the big drop in collective-based industrial disputes by developing initiatives that set out to settle legally-based employment disputes informally. Part of this work has involved refocusing its conciliation activities by offering a pre-claim conciliation (PCC) service to those involved in an Employment Tribunal case (Urwin et al. 2013). In addition, the organization has started to strongly promote mediation as a method for resolving workplace disputes. A high profile review of the employment tribunal system - the Gibbons Review - strongly advocated mediation as it viewed it as "a pragmatic, flexible and informal way of providing both parties with positive outcomes” (Gibbons 2007). As a result, ACAS has developed a range of new initiatives and pilot schemes to encourage the wider use of mediation amongst employers. Various assessments of these initiatives have found mediation to be an effective way of resolving certain types of disputes, but a big question mark exists about the extent to which this practice has diffused within organizations (Latreille 2011).

ACAS has also considerably expanded what can be loosely called its advisory services. It runs a telephone helpline providing information and advice to employees and employers involved in a workplace dispute. It spent considerable time developing the ACAS model workplace to provide best practice guidance on how organizations should manage their employees to secure high performance. Additionally, it is working closely with the UK’s National Health Service to manage the diffusion of innovative ADR practices to address collective and individual employment disputes. All in all, over the past decade ACAS has switched a huge swathe of internal resources away from collective-based employment disputes towards individual-based employment conflict. The aim of the organization is now to encourage non-judicial, informal methods of resolving workplace conflict and to promote employment practices that will help prevent disputes arising in the first place (Corby and Latreille 2012). 
A characteristic of the Irish public system to support employment dispute resolution is that it is fragmented across a range of agencies. The decline in collective disputes alongside the growth of legally-based employment disputes has led to a number of changes to the Irish system. First of all, considerably more resources have been allocated to the Rights Commissioners - there numbers have more than doubled- so that they can cope with the big increase in the number of individual employment rights disputes. In addition, a more comprehensive training and support programme has been devised for the Commissioners. Other parts of the employment dispute resolution system have also been introducing new programmes and policies, largely to promote the informal resolution of workplace conflict (see Teague and Thomas 2008). The Labour Relation Commission, which performs a similar role to that of ACAS in the UK, has shifted the emphasis away from collective conciliation. Instead, it has launched a new mediation service and increased its advisory services aimed at promoting high quality employment practices. Currently, the Irish employment dispute resolution system is being overhauled to make it less fragmented and more efficient. A likely result of these reforms is that mediation and preventive conflict management initiatives will acquire a stronger role (Teague 2013). In this respect, Ireland will be following the path being travelled by conflict management agencies in other Anglo-American countries.

As mentioned already the institutional adaption of public employment dispute resolution bodies in both Australia and New Zealand has been more politicized than in any other part of the Anglo-American world (Harbridge et al. 2006). Politically driven reform has led to a good deal of instability in the functioning of these bodies: policy innovation was designed more to meet political demands than to meet unfolding workplace conflict management developments. Over the past decade or so, both countries have left behind previous efforts to 'privatize' workplace conflict management. In New Zealand, a new Employment Relations Authority was 
created to reconstitute the public dispute resolution system. This Authority, like similar organizations in other Anglo-American countries, has placed mediation and preventive conflict management at the centre of its corporate strategy (Martin and Woodhams 2007). A variety of initiatives have been introduced to help firms diffuse innovative conflict management practices such as coaching and conflict mapping and monitoring. In addition, a number of early assistance schemes have been developed offering organizations a menu of mediation approaches to solve workplace problems. Informal conflict management is the key goal of the Employment Relations Authority (Rasmussen and Walker 2009).

Less emphasis is placed on informality in the new Australian public dispute resolution agencies introduced by the Fair Work Act. The Fair Work Commission has placed attention on collective industrial relations, particularly encouraging 'good faith' bargaining and a restoration of some form of awards systems that previously prevailed in the country (Cooper and Ellem 2009). Although the new Commission offers mediation as a service to address workplace problems, it has not committed to this procedure as much as dispute resolution agencies in other countries. Neither is it engaging to any significant extent with ADR practices that are so influential in the USA and Canada. Overall, the focus of the Fair Work Commission is out of step with the orientation of dispute resolution agencies in other Anglo-American countries. Domestic political circumstances lie behind this difference - it is not because collective industrial relations are thriving in the country. The only significant innovation that has occurred in Australia has been the creation of the Fair Work Ombudsman. The design and functioning of this service closely resembles the constitution of the Rights Commissioners in Ireland. The service seeks to combine an educational, problem-solving and enforcement role to ensure that employment laws are complied with at the workplace. Like Rights Commissioners, the Fair Work Ombudsman simultaneously pursues informal and formal strategies. It is innovative 
because it is seeking ways to not only improve employee knowledge of prevailing employment rights, but also to make it easier to vindicate these rights.

The preceding assessment suggests that public dispute resolution bodies across the AngloAmerican world are no longer primarily engaged in resolving big collective industrial relations disputes from which, paradoxically, they largely gained their institutional legitimacy. For sure, they continue to be engaged in the resolution of collective forms of workplace conflict, but everywhere there appears to be recognition that an exclusive focus on this type of work is the pathway to institutional marginalization. In nearly all Anglo-American countries, the emphasis is on developing new programmes and activities that are relevant to the smaller-scale, mostly individualized employment disputes that are replacing strikes and other forms of collective disputes as the dominant form of workplace conflict. In other words, most statutory dispute resolution bodies have launched a process of internal organizational mutation that seeks to complement the growth of individual employment rights by developing informal conflict management policies such as mediation. The big drawback with this approach is that these changes are being introduced in the context of too little being done to help employees vindicate employment rights.

< Table 2 here $>$

Table 2 synthesizes the institutional adaptations that have been triggered by the growth of rights-based workplace conflict and which have been reviewed in the last two sections. One easily discerned common pattern is the growth almost everywhere in informal procedures such as mediation and other ADR initiatives for the resolution of workplace conflict. The promotion of these arrangements should not be seen as being of a piece with efforts at the private ordering of the employment relationship: even in the circumstances of a strong supportive regime for the vindication of employment rights, public dispute resolution agencies are going to promote 
informal conflict management strategies. Thus, informal conflict management is likely to be a key future theme in the resolution of workplace conflict across the Anglo-American world.

The review also shows that attempts at the private ordering of the employment relationship through hindering the ability of employees to vindicate of employment rights has meet with different levels of success. The USA has travelled furthest down this road, followed closely by the UK. However, attempts at implementing such a strategy in Australia and New Zealand have been thwarted and Ireland and Canada have displayed no appetite for this reform pathway. Thus, nationally distinctive institutional architectures are being developed, and indeed still being contested, to house the common pattern of the growth of individual employment rights. Although the emergence of new business-friendly, individualized employment rights regimes are neither universal nor complete, there have been few decisive moves towards an employeefriendly regime of economic citizenship. With the exception of the USA, the trend across the Anglo-American world is for employment rights regimes and collective industrial relations processes to co-exist in an incoherent, disjointed manner.

\section{Conclusions}

This paper argues that the expansion of individual employment rights has been a key convergence dynamic within Anglo-American industrial relations systems. In contrast to much commentary, it suggests that this development is pretty significant: the proliferation of employment rights is considered to be part and parcel of the wider process of the juridification of economic and social life. Governments across the Anglo-American world have eagerly sought to mute the enforcement of employment rights. In addition, almost everywhere public or statutory dispute resolution agencies have sought to shred their organizational identity as provider of support services for collective industrial relations processes. Instead, they have 
been developing new services to be aligned more closely with the emerging trend of smallscale, mostly rights-based, forms of workplace conflict: they are engaged in an internal process of organizational renewal. The upshot of these institutional mutations is to further erode collective industrial relations processes.

Attempts at creating a private ordering of the employment relationship in response to the growth of employment rights legislation have been most successful in the USA, followed closely behind by the UK. Efforts in the other countries have been less successful. A near two decade political battle has been occurring in Australia and New Zealand about the institutional regime that should be created to house individual employment rights. Ireland and Canada have shown little appetite to initiate concerted public policies to liberalize the governance of the employment relationship. These quite contrasting institutional pathways suggest that nationally distinctive employment rights regimes are emerging across Anglo-American countries. However, an important convergence dynamic might be emerging across these countries as a result of the organizational renewal strategies being pursued by statutory dispute resolution agencies. In particular, the endeavours being made by these bodies to connect with the growing incidence of rights-based employment disputes may lend greater institutional support for the diffusion of innovative conflict management practices such as mediation. These developments suggest that the governance of the employment relationship in Anglo-American world will continue to display both similarities and differences. However, the emergence of employment rights regimes is changing the institutional character of these converging and diverging tendencies. Previously these countries diverged principally around the manner in which the institutionally housed the collective model of economic citizenship. Nowadays, they diverge on the institutional systems they are building for individual employment rights regimes that have emerged simultaneously across countries. 
Overall, the fallout from all the institutional activity that has been arisen in the wake of the growth of individual employment rights has been a further, if uneven, move away from the old collective model of economic citizenship. No decisive advance has been made towards a rightsbased model of economic citizenship which would allow for the more effective enforcement of employment legislation as well as the encouragement of decentralized social mobilization on improving the workplace for employees. For the most part, thinking about how employment rights can be utilized to promote employee-friendly policies remains underdeveloped. In most Anglo-American countries, the institutional toing-and-froing to establish the nature and scope of the architecture to house individual employment rights is likely to continue. As a result, economic citizenship in most of these countries is likely to be fragmented, consisting of an untidy mixture of both collective and rights-based processes being used to defend the interests of employees at the workplace. Unfortunately, an inevitable consequence of this fragmentation is that many employees will fall between the gaps of these collective and rights-based processes, marooned with no protection. 


\section{References}

Bingham, L. B. (2003). Mediation at Work: Transforming Workplace Conflict at the United States Postal Service. Arlington, VA: IBM Center for the Business of Government.

BIS (Department of Business, Innovation and Skills) (2011). Resolving Workplace Disputes: A Consultation. London: BIS.

Colling, T. (2010). 'Legal institutions and the regulation of workplaces'. In D. Colling and M. Terry (eds.), Industrial relations: theory and practice. Oxford: Wiley-Blackwell, pp 323346.

Colvin, A.J.S. (2012). 'American Workplace Dispute Resolution in the Individual Rights Era’. International Journal of Human Resource Management, 23: 3-4

Colvin, A.J.S. and Darbishire, O. (2013). 'Convergence in Industrial Relations Institutions: The Emerging Anglo-American Model?’ Industrial and Labour Relations Review, 66 (5): 1045-1075.

Cooper, R. and Ellem, B. (2009). 'Fair Work and the Re-regulation of Collective Bargaining'. Australian Journal of Labour Law, 22 (3): 284-305

Corby, S. and Latreille, P.L. (2012). 'Employment tribunals and the civil courts: Isomorphism exemplified’. Industrial Law Journal, 41(4): 387-406.

Dickens, L. (2012). 'Employment Tribunals and Alternative Dispute Resolution'. in L. Dickens (ed), Making Employment Rights Effective: issues of enforcement and compliance. Oxford: Hart Publishing, pp 29-47.

Dunlop, J., and Zack, A. (1997). The Mediation and Arbitration of Employment Disputes. San Francisco: Jossey-Bass

Edwards, P. (1986). Conflict at Work: A Materialist Analysis of Workplace Relations. Oxford: Blackwell 
Estlund, C. (2010). Regoverning the Workplace: From Self-Regulation to Co-Regulation. New haven: Yale University Press

Forsyth, A. (2012). 'Workplace conflict resolution in Australia: the dominance of the public dispute resolution framework and the limited role of ADR'. International Journal of Human Resource Management, 23 (3): 476-494.

Gibbons, M. (2007). A review of employment dispute resolution in Great Britain. London: DTI.

Grahl, J. and Teague P. (1994). 'Economic Citizenship in the New Europe'. Political Quarterly, 65 (4): 379-396.

Grills, W. (1994). 'The Impact of the Employment Contracts Act on Labour Law:

Implications for unions'. New Zealand Journal of Industrial Relations, 19(1): 85-101.

Habermas, J. (1987). The Theory of Communicative Action, Vol. 2. Boston: Beacon Press

Hahn, D. and Teague, P. (2012). 'Enforcing Individual Employment Rights: Lessons from the Rights Commissioners in the Republic of Ireland'. Work, Employment and Society, 26 (4): 623-637

Harbridge, R., Fraser, B., and Walsh, P. (2006). 'Industrial relations in Australia and New Zealand: the path from conciliation and arbitration’. In M. Morley, P. Gunnigle, and D. Collings (eds), Global Industrial Relations. Oxford: Routledge.

Heckscher, C. and McCarthy, J. (2014). 'Transient Solidarities: Commitment and Collective Action in Post- Industrial Societies’. British Journal of Industrial Relations, 54 (4): 627-657

Heery, E. (2010). ‘Debating employment law: responses to juridification’. In P. Blyton, E. Heery and P. Turnbull (eds.), Reassessing the Employment Relationship. Basingstoke:

Palgrave.

Kochan, T. A. (1999). 'Reconstructing America's Social Contract in Employment: The Role of Policy, Institutions, and Practices’. Chicago-Kent Law Review, 75 ( 1): 137-151

Jackson, G. and Kirsch, A. (2014): Employment Relations in Liberal Market Economies. In Wilkinson, A., Wood, G. and Deeg, R. (eds.) The Oxford Handbook of Employment Relations: Comparative Employment Systems. Oxford: Oxford University Press: 263-291.

Lansbury R. and Wailes N. (2011). 'Employment Relations Australia'. In Bamber, G. J., Lansbury R .D. and Wailes N. (eds), International and Comparative Employment Relations: Globalisation and Change (5th edition), Sydney, Australia: Allen \& Unwin, pp 117-37

Latreille, P. (2011). Workplace Mediation: A Thematic Review of the ACAS/CIPD Evidence. ACAS Research Paper, 13/11. 
Lewin, D. (2008). 'Conflict Resolution’. In Bacon, N., Blyton, P., Fiorito, J. and Heery, E. (eds.), Handbook of Industrial and Employment Relations, Thousand Oaks, CA: Sage, pp 447-467

Lipsky, D.B., and Avgar, A.C. (2008). 'Toward a Strategic Theory of Workplace Conflict Management'. Ohio State Journal on Dispute Resolution, 24(1): 143-190.

Lipsky, D.B., Seeber, R.L., and Fincher, R.D.( 2003). Emerging Systems for Managing Workplace Conflict: Lessons from American Corporations for Managers and Dispute Resolution Professionals. San Francisco, CA: Jossey-Bass.

Martin, M. and Woodhams, B. (2007). Personal Grievance Mediations Conducted at the Department of Labour: A Snapshot. Wellington: Department of Labour.

O’Sullivan, M., Turner, T., Kennedy, M. and Wallace J. (2015 Is Individual Employment Law Displacing the Role of Trade Unions? Industrial Law Journal first published online May 8, 2015doi:10.1093/indlaw/dwv010

Piore, M. and Safford, S. (2006). 'Changing Regimes of Workplace Governance, Shifting Axes of Social Mobilization and the Challenge to Industrial Relations Theory'. Industrial Relations: 45(3): 299-325

Pollert, A. (2007). 'Individual Employment Rights: Paper Tigers, fierce in appearance but missing in Tooth and Claw’. Economic and Industrial Democracy: 28(1):110-139

Polanyi, K. (1944). The Great Transformation. New York: Farrar \& Rinehart

Rasmussen, E. and Walker, B. (2009). 'Employment Relations in the Millennium'. In E. Rasmussen (ed.), Employment Relations in New Zealand. Auckland: Pearson Education, chapter 6.

Rosanvallon, P. (2006). La Contre-démocratie: la Politique à l'age de la defiance, Paris, Le Seuil

Ryan, P. (2010). 'Training Markets'. In P. Peterson, E. Baker, and B. McGaw (eds), International Encyclopedia of Education, vol. 8, Oxford: Elsevier: 496-502

Saundry R. and Dix, G. (2014). 'Conflict Resolution in the UK'. In W. Roche, P. Teague and A. Colvin (eds), The Oxford Handbook on Conflict Management, Oxford: Oxford University Press

Slinn, S. and Hurd, R. W. (2011). 'First Contract Arbitration and the Employee Free Choice Act: Multi-Jurisdictional Evidence from Canada’. Advances in Industrial and Labor Relations: 18: 41-86

Smith, P. and Morton, G. (2006). 'Nine Years of New Labour: Neoliberalism and Workers' Rights’. British Journal of Industrial Relations: 44(3): 401-420.

Stone, K. (2000). Private Justice: The Law of Alternative Dispute Resolution, New York: 
Foundation Press

Streeck, W. (2005). ‘The Sociology of Labor Markets and Trade Unions’ In N. J. Smelser and R. Swedberg (eds.), The Handbook of Economic Sociology, Second Edition. Princeton: Princeton University Press, pp 254-283.

Streeck, W. (2012). 'Skills and Politics: General and Specific'. In M R. Busemeyer and C. Trampusch (eds.), The Political Economy of Collective Skill Formation. Oxford: Oxford University Press: pp 317-352.

Strimling, A. (2002). 'The Federal Mediation and Conciliation Service: A Partner in International Conflict Prevention'. Pepperdine Dispute Resolution Law Journal, 2(3): 178191

Teague, P. (2013). Resolving Workplace Disputes in Ireland: The Role of the Labour Relations Commission, Geneva: ILO

Teague, P. and Thomas, D. (2008). Employment Dispute Resolution and Standard-Setting in the Republic of Ireland, Dublin: Oaktree Press

Teicher, J., Lambert, R., and O’Rourke, A. (eds.) (2006). Workchoices: The New Industrial Relations Agenda, Frenchs Forest, NSW: Pearson.

Thompson M and Slinn S. (2013). 'Public Sector Industrial Relations in Canada: Does It Threaten or Sustain Democracy?' Comparative Labor Law and Policy Journal, 34 (2): 393409.

Touffut, J. P. (2003) Advancing Public Goods, Cheltenham, UK and Northampton, MA, USA

Troy, L. (2000). 'U.S. and Canadian Industrial Relations: Convergent or Divergent?' Industrial Relations, 39(4): 695-713.

Urwin,P., Buscha,F. and Latreille, P.L. (2013). 'Representation in UK Employment Tribunals: Analysis of the 2003 and 2008 Survey of Employment Tribunal Applications (SETA)'. British Journal of Industrial Relations, 46(4): 674-701.

Van Gramberg, B. (2006). Managing Workplace Conflict: Alternative Dispute Resolution in Australia. Sydney: Federation Press.

Waldegrave, T., Anderson, D., and Wong, K. (2003). Evaluation of the Short Term Impacts of the Employment Relations Act 2000. Wellington: Department of Labour.

Walker, B. and Hamilton, R. T. (2009). 'Grievance Processes: Research, Rhetoric and Directions for New Zealand’. New Zealand Journal of Employment Relations, 34(3): 43-64.

Walsh, P. (1993). 'The State and Industrial Relations in New Zealand'. In B. Roper and C. Rudd (eds), State and Economy in New Zealand. Auckland: Oxford University Press. 
Figure 1

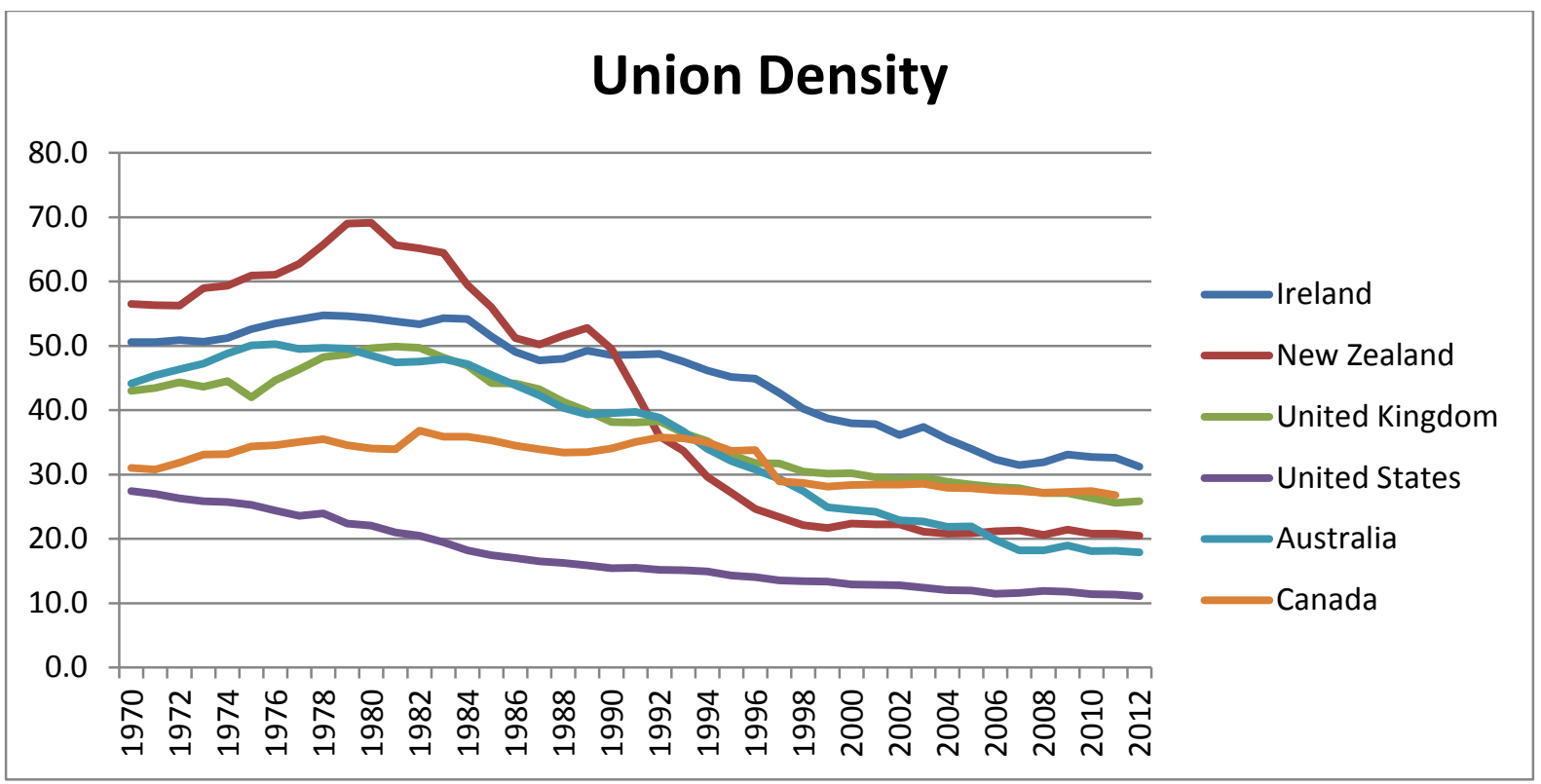

Figure 2

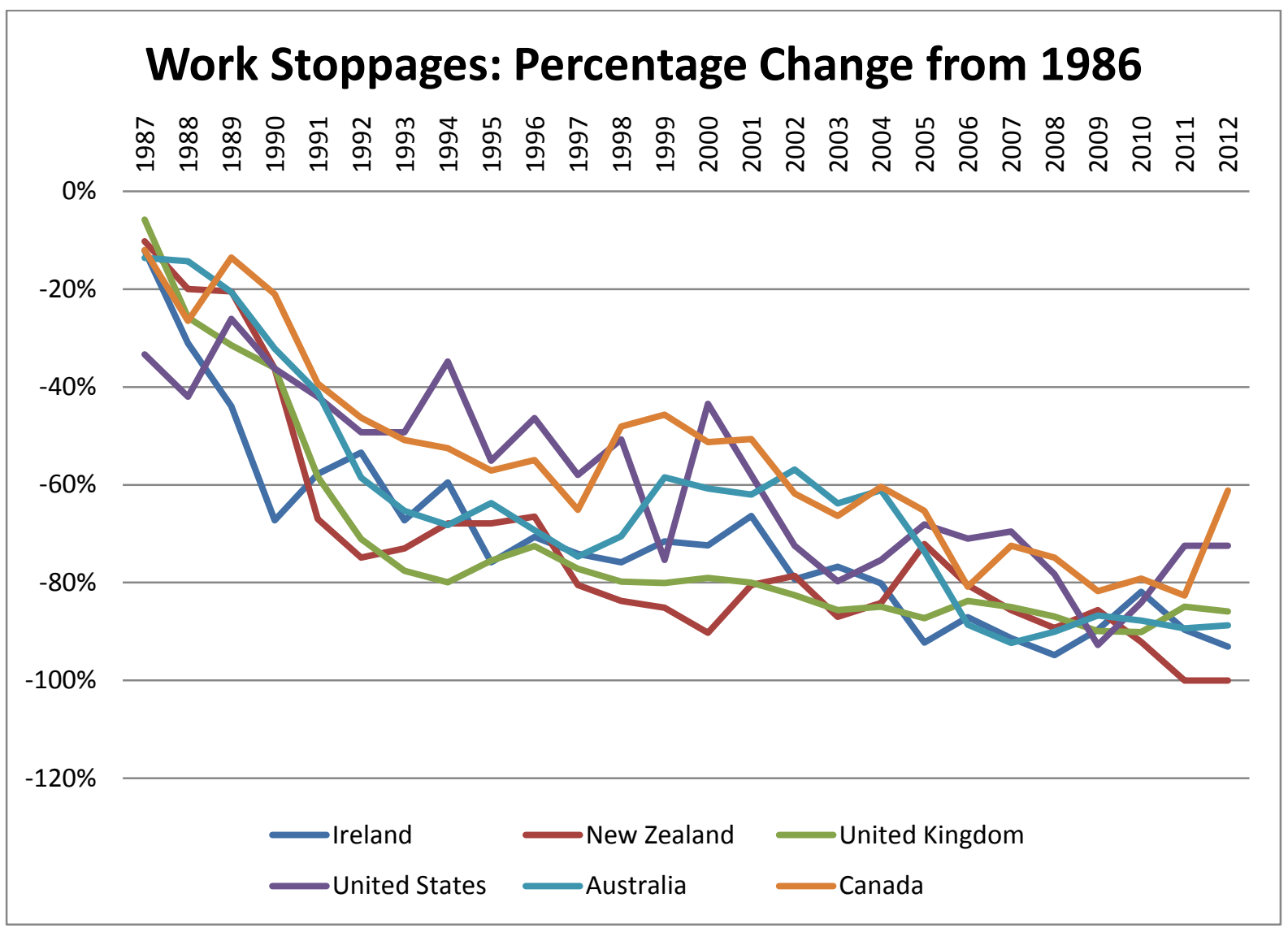


Table 1: Individual Employment Rights in Anglo-American Countries

\begin{tabular}{|c|c|c|c|c|c|c|}
\hline & USA & Canada & $\begin{array}{c}\text { New } \\
\text { Zealand }\end{array}$ & Australia & UK & Ireland \\
\hline $\begin{array}{l}\text { Minimum } \\
\text { Wage }\end{array}$ & $\checkmark$ & $\checkmark$ & $\checkmark$ & $\checkmark$ & $\checkmark$ & $\checkmark$ \\
\hline $\begin{array}{l}\text { Working } \\
\text { Hours and } \\
\text { Overtime }\end{array}$ & $\checkmark$ & $\checkmark$ & $\checkmark$ & $\checkmark$ & $\checkmark$ & $\checkmark$ \\
\hline $\begin{array}{c}\text { Holiday } \\
\text { Entitlement } \\
\text { and Pay }\end{array}$ & $\checkmark$ & $\checkmark$ & $\checkmark$ & $\checkmark$ & $\checkmark$ & $\checkmark$ \\
\hline $\begin{array}{c}\text { Regulation of } \\
\text { Part-Time } \\
\text { Work }\end{array}$ & & & $\checkmark$ & $\checkmark$ & $\checkmark$ & $\checkmark$ \\
\hline $\begin{array}{c}\text { Regulation of } \\
\text { Temporary } \\
\text { Work }\end{array}$ & & & $\checkmark$ & $\checkmark$ & $\checkmark$ & $\checkmark$ \\
\hline $\begin{array}{l}\text { Health and } \\
\text { Safety at } \\
\text { Work }\end{array}$ & $\checkmark$ & $\checkmark$ & $\checkmark$ & $\checkmark$ & $\checkmark$ & $\checkmark$ \\
\hline Equal Pay & $\checkmark$ & $\checkmark$ & $\checkmark$ & $\checkmark$ & $\checkmark$ & $\checkmark$ \\
\hline $\begin{array}{c}\text { Equal } \\
\text { Treatment }\end{array}$ & $\checkmark$ & $\checkmark$ & $\checkmark$ & $\sqrt{ }$ & $\checkmark$ & $\checkmark$ \\
\hline $\begin{array}{l}\text { Maternity and } \\
\text { Paternity } \\
\text { Rights }\end{array}$ & $\checkmark$ & $\checkmark$ & $\checkmark$ & $\checkmark$ & $\checkmark$ & $\checkmark$ \\
\hline Discrimination & $\checkmark$ & $\checkmark$ & $\checkmark$ & $\checkmark$ & $\checkmark$ & $\checkmark$ \\
\hline $\begin{array}{l}\text { Disability } \\
\text { Rights }\end{array}$ & $\checkmark$ & $\checkmark$ & $\checkmark$ & $\checkmark$ & $\checkmark$ & $\checkmark$ \\
\hline $\begin{array}{c}\text { Rights Against } \\
\text { Unfair } \\
\text { Dismissal }\end{array}$ & $\checkmark$ & $\checkmark$ & $\checkmark$ & $\checkmark$ & $\checkmark$ & $\checkmark$ \\
\hline
\end{tabular}




\section{Table 2: Workplace Conflict and Economic Citizenship: Institutional Developments in Anglo-American Countries}

Australia Growth in individual employment rights legislation has led to a big increase in the number of rights-based cases being addressed by statutory dispute resolution agencies. This development has been the centre of highly contentious political activity: right-of-centre Governments have sought to weaken the statutory dispute resolution agencies and promote the private ordering of the employment relationship whereas left-of-centre Governments have sought to modernise these agencies so that these can address both collective and rights-based disputes. The existing Fair Work Commission has sought to introduce interesting innovations such as the Fair Work Ombudsman that seeks to make it easier for employees to vindicate employment rights. Greater emphasis is placed by the dispute resolution agencies on the use of practices such as mediation to resolve conflict informally at the workplace.

The Canadian case is complex as both federal and provincial levels of government have an active role in the resolution of workplace conflict, but it is mostly a story of institutional continuity: there has been no concerted effort to uproot established statutory dispute resolution agencies, although small scale reforms have been introduced in response to the growth of rights-based employment disputes. The country's FCMS has been actively promoting mediation and other ADR practices to develop a strong non-judicial pathway for the resolution of rightsbased employment cases. The Public Service Relations Board in the early 2000s launched an innovative Informal Conflict Management initiative with the aim of diffusing in different parts of the public sector a set of interrelated ADR procedures. The emphasis has been on the development of informal workplace conflict management at all levels without any attempt being made to weaken the vindication of employment rights through the law.

Ireland The standout feature of the statutory dispute resolution regime in Ireland is the Rights Commissioners service, which individual employee can access relatively easily to vindicate employment rights. Rights Commissioners use a form of med/arb to resolve dispute. A twenty year regime of social partnership has kept in check any public policy moves towards the private ordering of the employment relationship. The main dispute resolution agency, the LRC, has adopted a new mediation programme and developed other advisory, which is in line with their counterparts elsewhere. Currently the statutory dispute resolution machinery is being overhauled for efficiency and not ideological reasons, but the consequence is likely to be an even greater emphasis being placed on preventive and informal forms of conflict management in the future. 
Like Australia, the emergence of individual employment rights legislation has been a contentious political issue. A concerted effort was made to dismantle the country's statutory dispute resolution machinery by a right-of-centre Government in the early 1990s and to effectively 'privatise' the resolution of workplace conflict. A subsequent Labour Government reversed these reforms and actually sought to revive collective mechanisms for the resolution of disputes. These efforts have met with modest success and individual forms of employment conflict continue to dominant. The Employment Relations Authority which was created in the early 2000s has placed mediation and preventive conflict management at the centre of its strategy to support workplace conflict resolution.

During the past decade or so there has been a massive expansion in the number of rights-based employment cases being addressed by the country's system of Employment Tribunals. As a result of this development, the growth of individual employment rights legislation has been framed as part of the wider campaign to reduce burdens on business. Thus, the main thrust of public policy has been to develop informal procedures such as mediation to resolve workplace problems within organizations. The current Coalition Government has introduced for the first time an obligation that employees seeking to bring a case to an Employment Tribunal must pay a fee. The collective dispute resolution activity of the country's main statutory workplace conflict management agency, ACAS, has all but collapsed: it mainly engages in the promotion of informal conflict management procedures such as mediation as well as the provision of advisory services.

The USA is exceptional in the Anglo-American world in having no appellant court or body to address specifically legally-based employment cases. A Supreme Court ruling in the Gilmer case allowed organizations to oblige employees to use arbitration rather than the judicial system to resolve legally-based employment disputes. In the wake of this ruling, research suggests that there has been a huge expansion in the use by organizations of ADR practices to address workplace conflict. The country's FCMS has moved considerably away from assisting trade unions and employers settle collective bargaining disputes; instead it now offers a suite of services to organizations, both domestically and internationally, to a resolve a wide range of conflicts outside of the employment relationship. Overall, the USA has gone further towards the private ordering of the employment relationship than other Anglo-American country. 